\title{
PROWINCJA (WĘG. VIDÉK) W WYBRANYCH WĘGIERSKICH FILMACH FABULARNYCH. ASPEKT SPOŁECZNY, POLITYCZNY I HISTORYCZNY
}

\author{
GRZEGORZ BUBAK ${ }^{1}$ \\ (Kraków)
}

Słowa kluczowe: węgierska prowincja, film, epoka kádárowska, stolica

Keywords: Hungarian countryside, film, Kádár regime, capital city

\begin{abstract}
Abstrakt: Grzegorz Bubak, PROWINCJA (WĘG. VIDÉK) W WYBRANYCH WĘGIERSKICH FILMACH FABULARNYCH. ASPEKT SPOŁECZNY, POLITYCZNY I HISTORYCZNY. „PORÓWNANIA" 11, 2012, Vol. XI, ss. 183-192, ISSN 1733-165X. Analizując sposób prezentacji tzw. prowincji (węg. vidék) w filmie węgierskim, można dostrzec kilka wariantów tego zagadnienia. Najbardziej powszechnym, wręcz klasycznym jest ukazanie jej jako stron rodzinnych, miejsca urodzenia. To właśnie stąd bohaterowie filmów wyjeżdżają, uciekają, przenoszą się do wielkiego miasta, by odmienić swoje życie. Niektórzy z nich z premedytacją zrywają rodzinne więzi, dawne kontakty, by całkowicie odciąć się od swoich korzeni, inni z sentymentem będą wspominać lata dzieciństwa. Są też filmy, których fabuła rozgrywa się wyłącznie na prowincji, widz śledzi wtedy charakterystyczne rytuały, zwyczaje. Nie zawsze prowincja, jako przestrzeń jest ukazana bezpośrednio, czasem tylko jako pewien punkt odniesienia, wspomnienie, ale także sposób myślenia, zachowania.
\end{abstract}

\begin{abstract}
Grzegorz Bubak, THE PROVINCES (HUNGARIAN VIDÉK) IN CHOSEN HUNGARIAN FEATURE FILMS. SOCIAL, POLITICAL AND HISTORICAL ASPECTS. „PORÓWNANIA" 11, 2012, Vol. XI, pp. 183-192, ISSN 1733-165X. Analyzing the occurrence of the so-called countryside in the Hungarian films, one can see several variants of this problem. This is the place from which main character escapes, moves to the big city to change his live. Some of individuals deliberately disunite family ties and old contacts, to completely cut off from their roots. Others will remember with fondness their childhood. There are also movies where the story takes place exclusively in the countryside, then the viewer follows the characteristic rituals and customs of the scenery. It is not always the countryside shown directly, sometimes only as a reference point, a memory, but also a way of thinking and behaving as well.
\end{abstract}

\footnotetext{
${ }^{1}$ Correspondence Address: grzegorzb@konto.pl
} 
Podział na Budapeszt i resztę kraju jest niemalże tak stary jak historia miasta (w zasadzie dwóch miast: Budy i Pesztu), jeszcze bardziej widoczny od roku 1950, kiedy to $w$ granice stolicy włączono 23 okoliczne miejscowości. Dotyczy on nie tylko kwestii czysto administracyjnej, także sfery mentalnej, bardzo mocno zakorzenionej w umysłach Węgrów żyjących dawniej i dziś. Państwo węgierskie ma zupełnie inną strukturę administracyjną i demograficzną niż np. Polska. Stolica naszego kraju, posiadając wszystkie należne atrybuty, ma także silną konkurencję $\mathrm{w}$ innych miastach pod względem gospodarczym, kulturalnym. Do tego dochodzi brak tak wielkich dysproporcji w liczbie mieszkańców jak na Węgrzech². Budapeszt odgrywał i odgrywa decydującą rolę prawie we wszystkich dziedzinach życia. Budapeszt z racji swojej pozycji był w czasach Austro-Węgier drugą, obok Wiednia, stolicą tego wielkiego państwa, od decyzji tu podejmowanych zależały losy tak odległych od niego terytoriów jak Chorwacja czy Slawonia. Życie naukowe i kulturalne rozwijało się na przestrzeni wieków, łącząc tradycję z nowoczesnością. W związku z tym nie może dziwić, że przyciągał twórców, artystów, dziennikarzy, polityków, ale także prostych ludzi szukających zmian, poprawy swojej egzystencji. Aby o tym się przekonać, wystarczy sięgnąć do życiorysów znanych postaci z przeszłości, jak i teraźniejszości Węgier. Urodzeni poza stolicą, studia czy pierwszą pracę podejmują już w Budapeszcie. Reszta kraju, wpatrzona i zasłuchana $\mathrm{w}$ wydarzenia $\mathrm{z}$ centrum, pozostawała $\mathrm{w}$ cieniu ${ }^{3}$. Inne ośrodki miejskie pełniły i w dalszym ciągu pełnią istotne role, ale tylko o charakterze regionalnym. W dobie komunikacji internetowej sprzyjającej decentralizacji, być może to się zmieni, ale na pewno nie zagrozi pozycji Budapesztu. W dalszym ciągu stolica koncentruje ważne gałęzie m.in. przemysłu elektronicznego, farmaceutycznego, ponad połowa przedstawicielstw zagranicznych firm obecnych na Węgrzech ma swoją siedzibę właśnie w tym mieście. Dominuje ono pod względem rynku finansowego i nieruchomości, z rozbudowaną infrastrukturą turystyczną, z ponad tysiącem restauracji i kawiarni nie ma konkurencji w kraju. Podobnie jest w przypadku mediów, rynku reklamowego, nadawców telewizyjnych i przemysłu filmowego. Dlatego też problem związany z dominacją stolicy, umiejscowieniem prowincji, który wpływa na kształtowanie się społeczeństwa węgierskiego jest obecny i widoczny także w sztuce, przekazie artystycznym, w filmie. Warto zatem prześledzić ten wątek tematyczny w kinie węgierskim, bowiem stanowi on odręb-

2 W szczytowym okresie (lata dziewięćdziesiąte), przed reurbanizacją w Budapeszcie mieszkało prawie 2,1 mln ludzi, co stanowiło ponad 20 procent obywateli całego kraju, obecnie jest to ok. 18 procent.

${ }^{3}$ Kwestia ta jest dobrze widoczna np. w filmie dokumentalnym 1956 - a salgótarjáni sortűz (Péter Vékás, 2006) opowiadającym o rewolucji 1956 roku właśnie z perspektywy prowincji, świadkowie tamtych wydarzeń mówią m.in. o tym, że wiedzieli, że w Budapeszcie miały miejsce demonstracje, ale nie do końca orientowano się, co tam się stało. 
ny i równocześnie ciekawy nurt. Reprezentują go filmy twórców różnych pokoleń, co świadczy o ponadczasowym zainteresowaniu tą problematyką.

Analizując sposób prezentacji tzw. prowincji w filmie, po węgiersku vidék, można dostrzec kilka wariantów tego zagadnienia. Najbardziej powszechnym, wręcz klasycznym jest ukazanie jej jako stron rodzinnych, miejsca urodzenia. To właśnie stąd bohaterowie filmów wyjeżdżają, uciekają, przenoszą się do wielkiego miasta, by odmienić swoje życie. Niektórzy z nich z premedytacją zrywają rodzinne więzi, dawne kontakty, by całkowicie odciąć się od swoich korzeni, inni z sentymentem będą wspominać lata dzieciństwa, część z nich powraca lub odwiedza krewnych. Są też filmy, których fabuła rozgrywa się wyłącznie na prowincji, widz śledzi wtedy charakterystyczne rytuały, zwyczaje. Nie zawsze prowincja jako przestrzeń jest ukazana bezpośrednio, czasem tylko jako pewien punkt odniesienia, wspomnienie, ale także sposób myślenia, zachowania. Doskonałym przykładem wariantu ucieczki jest debiutancki film Ágnes Incze pod wiele mówiącym tytułem Kocham Budapeszt (I love Budapest, 2001). Bohaterką jest młoda, naiwna dziewczyna, która wyrusza do wielkiego miasta w poszukiwaniu lepszego, ciekawszego życia. Anikó (Gabriella Hámori), skuszona listem koleżanki zachwalającej uroki stolicy, wyrusza na spotkanie swojego losu i niestety właściwie bardzo szybko okazuje się, że nie wszystko potoczy się według najszczęśliwszego scenariusza. Jednak trudności nie przeszkadzają idealizować otaczającego świata. Pobyt w stolicy jest dokładnym przeciwieństwem dotychczasowego życia bohaterki, tu czeka wiele atrakcji, energiczni rówieśnicy, bogate życie nocne i - mimo kiepskiej pracy w brudnej fabryce - Budapeszt ma to "coś", czego brakuje rodzinnej miejscowości. Życie tam toczy się leniwie i tylko od czasu do czasu na horyzoncie pojawia się zmierzający do miasta autobus. Anikó nie wróci do rodzinnego domu, bowiem dostrzega tylko pozytywne strony nowego miejsca, jest za młoda, by darzyć swoją wieś sentymentem i wspominać jej mieszkańców, krewnych. Dziewczyna nie wyjechała w poszukiwaniu pieniędzy, więc nawet ich brak, kiepsko płatna praca nie będzie powodem do powrotu. Można powiedzieć, że motyw prowincji ukazany jest tu bardziej w sferze mentalnej, pewnych ograniczeń, z których uwolnić się chce bohaterka i jej rówieśnicy. Podobny motyw eskapizmu zastosował mistrz kina węgierskiego István Szabó w swoim pierwszym po sukcesach zagranicznych (Trylogia Środkowo-Europejska czyli Mefisto, 1981, Pułkownik Redl, 1985, Hanussen, 1988 oraz Schadzka $z$ Wenus, 1991) filmie Kochana Emmo, droga Böbe (Édes Emma, drága Böbe - vázlatok, aktok, 1992). To przejmująca historia dwóch młodych kobiet, które w poszukiwaniu szczęścia w życiu osobistym, sukcesu zawodowego i zdobycia szacunku otoczenia przenoszą się do Budapesztu. Historia sprawiła, że ich pobyt zbiegł się z wielkimi zmianami, runął mur berliński, system komunistyczny upadł, János Kádár stał się tylko postacią historyczną. Bezpieczne do tej pory, za sprawą małej stabilizacji, z dnia na dzień tracą grunt pod nogami. Nauczycielki języka rosyjskiego przez kolegów i koleżanki z pracy traktowane są 
teraz z pogardą, wręcz wrogością, uczniowie natomiast ostentacyjnie okazują swoje lekceważenie (znamienna scena palenia na podwórku szkolnym podręczników do nauki tego języka). W tym kontekście obraz prowincji z jednej strony jest przesycony sentymentalnym podejściem, $\mathrm{z}$ drugiej natomiast - kojarzy się mocno z dawnym życiem, od którego należało uciec.

Kiedyś rodzinny dom Emmy był dla niej balastem, którego próbowała się pozbyć wyruszając na podbój świata. Żegnała ów bez żalu. Chciała zapomnieć o jego fasadzie pomalowanej żółcią Marii Teresy, o ogródku pełnym kolorowych kwiatów, strychu przechowującym pamięć o ludziach i rzeczach, także o stole kuchennym, na którym obok dużego bochenka białego pszennego chleba, w plamach ostrego słońca leży zielona i czerwona papryka. Dziś, gdy Emma czuje się samotnie i obco, a czuje się tak nader często, wszystko to kusi przytulnym ciepłem, lecz Emma nie chce wracać, bowiem powrót oznaczałby dla niej przyznanie się do porażki. A na to Emma jest zbyt ambitna ${ }^{4}$.

Dlatego też rozpaczliwe będą próbowały wszelkimi sposobami uchronić się przed powrotem, jedna z nich tą walkę o przetrwanie przypłaci, niestety, życiem. Skoro o filmowej twórczości I. Szabó mowa to warto w kontekście życia na prowincji wspomnieć także film Krewni (Rokonok, 2006) jedną z trzech ekranizacji utworu Zsigmonda Móricza. Tekst powstał w okresie międzywojennym (1930r.) i jest doskonałym odzwierciedleniem, wnikliwą obserwacją panujących ówcześnie stosunków społecznych z dala od centrum kraju. Tłem wydarzeń jest fikcyjne miasteczko Zsarátnok, leżące gdzieś na Wielkiej Nizinie. W rzeczywistości Móricz opisał w swojej powieści Debreczyn, ale, nie chcąc konfrontacji z władzami miasta, dla bezpieczeństwa wymyślił na potrzeby powieści nazwę miejscowości. Głównym zagadnieniem jego dzieła jest wszechobecna korupcja panosząca się na wszystkich szczeblach władzy, od tej lokalnej aż po centralną, od której zależą losy państwa. Mała miejscowość dodatkowo stwarza okazję dla jej rozwoju, tutaj wszyscy się znają, a co ważniejsze, są ze sobą w jakiś sposób spokrewnieni - „mały kraj, dużo krewnych" mówi jedna z postaci. To często jest usprawiedliwieniem, rozgrzeszeniem nielegalnych działań. Odczuwalny kompleks prowincjonalności widać dobrze, kiedy któryś z bohaterów filmu jedzie np. służbowo do Budapesztu. Jest to wyprawa do nieomal biblijnej ziemi obiecanej, także miejsca, które napawa lękiem, ale równocześnie dodaje prestiżu. Elementem łączącym te dwa światy jest podróż koleją, w trakcie której dzieją się dziwne, tajemnicze i niespodziewane rzeczy.

We wczesnym filmie kolejnego węgierskiego klasyka Miklósa Jancsó Światło na twarzy (Oldás és kötés, 1963) widać wiele podobieństw do późniejszego sposobu ukazywania dychotomii Budapeszt - prowincja; film powstał wprawdzie na długo wcześniej przed zmianą systemu, ale przywołuję go właśnie $\mathrm{z}$ tego powodu.

${ }^{4}$ K. Żórawski, Samotna Emma, nieszczęsna Böbe. „Kino” 1992, nr 9, s. 32. 
W filmie tym wspomniane zagadnienie dwudzielności występuje jednak $\mathrm{w}$ wariancie powrotu $\mathrm{w}$ rodzinne strony. To kolejny etap życia bohaterów, kiedy po okresie aklimatyzacji w stolicy podejmują decyzję o odwiedzinach najbliższych. Krok ten spowodowany jest różnymi przyczynami: np. brakiem stabilizacji, rozczarowaniem życiem w dużym mieście, tęsknotą za rodziną, albo wręcz odwrotnie, chęcią pochwalenia się swoimi sukcesami. Mogą to być osiągnięcia zawodowe, zmiana statusu społecznego, a w mniejszych miejscowościach swoje znaczenie ma nawet zaprezentowany tam narzeczony. Film M. Jancsó to opowieść o życiu młodego chirurga, Ambrusa mieszkającego w Budapeszcie, który przeżywa kryzys związany z pracą oraz życiem osobistym. Emocjonalne wahania wywołane są dramatycznym zdarzeniem $\mathrm{w}$ szpitalu. $\mathrm{W}$ trakcie operacji młodej kobiety jego dużo starszy kolega po fachu nagle słabnie. Potrzebna jest szybka interwencja pozostałych lekarzy. Ambrus uświadamia sobie wtedy, że życie ludzkie mija bardzo szybko i nawet w wieku trzydziestu lat trzeba już poczynić pewne podsumowania. Zauważa, nie bez żalu, że jego dotychczasowa egzystencja przebiegała bezrefleksyjnie, beztrosko i łagodnie pokonywał kolejne etapy na swojej drodze. Być może ten wstrząs był mu potrzebny, by uświadomić sobie, że jeśli sukcesy przychodzą zbyt łatwo, człowiek nie docenia spraw istotnych. Podróż $\mathrm{w}$ rodzinne strony odbywa niejako $\mathrm{w}$ ramach rachunku sumienia. Właśnie wyprawa na spokojną węgierską wieś jest ważną częścią filmu Jancsó. Bohater wraca do rodzinnego domu, by razem z ojcem przy posiłku i winie zastanowić się nad swoją przyszłością. Nie udaje mu się namówić ojca, by zamieszkał z nim w Budapeszcie, sam zresztą nie wierzy w skuteczność tej prośby. Utwierdza się jednak w przekonaniu, że wyjazd na studia był mu potrzebny. Spotyka również swoją dawną miłość, kobietę, którą wyjeżdżając odrzucił. Ona natomiast została i mimo trudności też zrobiła karierę, założyła rodzinę. Czarno-biała taśma filmu, mimo swoich ograniczeń, ale dzięki doskonałym zdjęciom i wykorzystaniu naturalnego światła, pozwala niemalże dostrzec prawdziwe barwy krajobrazu: rozległych pól ciągnących się po horyzont, skoszonego zboża po żniwach. Jancsó wykorzystuje długie ujęcia, daleką perspektywę wielkich przestrzeni węgierskiej prowincji z wiejskimi domami, żurawiami przy studniach tak charakterystycznymi dla puszty. Film zrealizowano na początku lat sześćdziesiątych, w okresie, kiedy system kádárowski cementował się, rozpoczynał się czas konsolidacji politycznej, pożądanym było ukazywanie pozytywnych stron coraz mniej represyjnego systemu. Film wprawdzie nie jest laurką ustroju, ale miasto jest tu nowoczesne - szpital świetnie wyposażony, lekarze to profesjonaliści, ulice ruchliwe; wieś natomiast jest trochę zacofana (ojciec bohatera pracuje na roli bez traktora), ale za to jawi się jako oaza spokoju. Zasadnicza różnica w ukazaniu tych dwóch światów polega na tempie życia, na wsi Ambrus ma czas, by usiąść na trawie i delektować się majestatycznym krajobrazem. W mieście nie ma możliwości, ani okazji na takie przyjemności. W kinie najnowszym podobne spojrzenie można odnaleźć np. w komedii Podróżnicy (Kalandorok, 2007), Béli Paczolaya. 
Krisztina Deák, znana węgierskiej publiczności z realizacji m.in. Książki Estery (Eszterkönyv 1989), Mgty (Köd, 1993) i Bonnie i Clyde z Miszkolca (A miskolci boniésklájd, 2004) zrealizowała w 1999 film Poduszka Jadwigi (Jadviga párnája) według głośnej książki Pála Závady pod tym samym tytułem wydanej również w Polsce. Wersja literacka okazała się prawdziwym przebojem wydawniczym wielokrotnie wznawianym i równie często nagradzanym, m.in. prestiżowym wyróżnieniem im. Attili Józsefa.

Akcja filmu toczy się w początkach dwudziestego wieku, natomiast książka jest opisem kilku dekad tamtego samego stulecia. Kluczowym zagadnieniem dzieła filmowego jest ciekawa i trudna zarazem problematyka narodowościowa będącej u schyłku monarchii austro-węgierskiej. Reżyserka, jak sama stwierdziła, była zafascynowana koegzystencją narodów, wyznań i harmonią w jakiej żyły (do pewnego momentu) odmienne kultury, często czerpiąc wzajemnie z bogatej historii. To właśnie na prowincji kształtowały się bezpośrednie relacje mieszkańców tego ogromnego państwa, które już niedługo zdecydują o jego losach. Ilustracją tego zjawiska jest słowacka wioska na terenie dogorywającej monarchii, gdzie dwujęzyczność jest czymś normalnym, a wybór języka bywa uzależniony od stanu emocjonalnego mówiącego (język węgierski służy do formalnych kontaktów, natomiast słowacki staje się językiem emocji, gwałtownych reakcji). Wychowany w takiej właśnie społeczności autor książki i zarazem współscenarzysta filmu doskonale znał opisane realia, co w wiarygodny sposób zostało przeniesione na duży ekran. Dostrzec można pewną nostalgię za minioną wielokulturowością krajobrazu węgierskiego, która zniknęła wraz ze zmianą granic po wejściu w życie postanowień traktatu $\mathrm{z}$ Trianon.

Główna bohaterka, tytułowa Jadwiga, niespełniona w miłości i tak naprawdę samotna, i wyobcowana na prowincji, coraz częściej tęskni za życiem w mieście. Film ten pokazuje doskonale, że skrajne emocje, silne uczucia są tożsame zarówno dla mieszkańców wsi, małych miejscowości, jak i wielkich metropolii.

Dzięki twórczości Róberta Koltaiego, aktora i reżysera, możemy prześledzić kilka różnych, ale $\mathrm{w}$ sumie do siebie podobnych sposobów ukazania prowincji w kinie węgierskim. Mam na myśli filmy Nigdy nie umrzemy (Sose halunk meg, 1993), Samba (Szamba, 1996), Niech żyje pierwszy maja (Csócsó, vagyis éljen május elseje, 2001) i Numer światowy (Világszám, 2004). Wszystkie te realizacje utwierdzają klasyczny obraz prowincji jako miejsca, gdzie życie toczy się odmiennym rytmem i według własnych standardów, niezależnie od epoki, systemu politycznego. Nigdy nie umrzemy (węgierski kandydat do nagrody Amerykańskiej Akademii Filmowej) to nostalgiczna opowieść głównego bohatera, który wspomina swojego bliskiego krewnego. Razem $\mathrm{z}$ nim w młodzieńczych latach odbył podróż po niewielkich miejscowościach węgierskiej prowincji. Na prezentowany obraz tej przestrzeni nakładają się bardzo subiektywne elementy, bohater wspomina wspólne doświadczenia z wieloletniej perspektywy. Nie wszystko przed laty mu- 
siało wyglądać dokładnie tak jak teraz, ponadto obraz widziany oczami bardzo młodego człowieka jest wyidealizowany, wybiórczo rejestruje otoczenie, np. pozostają mu wyraźne wspomnienia na temat inicjacji seksualnej, ale już nie o politycznej sytuacji ówczesnych Węgier (z wyjątkiem milicjanta w męskiej toalecie, który staje się agresywny na dźwięk słowa wolność). Bohater nie dostrzega tamtych problemów, trudności, z jakimi na co dzień musiało się zmagać niemal całe społeczeństwo. Pamięta jednak, że ludzie byli życzliwi i w miarę możliwości pomocni.

Samba z kolei opowiada o trudnej relacji ojca i syna w stalinowskiej rzeczywistości prowincjonalnego miasteczka. Senior, tytułowy Samba, pragnie zaszczepić swojemu następcy miłość do teatru, poezji, nie bierze jednak pod uwagę lub może tego nie dostrzega, że jego osiągnięcia na tym polu raczej zniechęcają syna. $\mathrm{W}$ wolnych od zawodowych obowiązków chwilach z wielkim oddaniem, autentyczną pasją reżyseruje okolicznościowe przedstawienia, akademie rocznicowe, w których sam zresztą występuje. Jest przekonany, że sztuka w jego wykonaniu niczym nie ustępuje tej, którą nieudolnie próbuje naśladować. Junior Samba patrzy bardzo krytycznie na dokonania ojca. Szybko okaże się, że nie pójdzie tą drogą, jego ambicje sięgają dalej niż zostanie gwiazdą lokalnej społeczności. Wyjeżdża do Budapesztu, ponieważ, na przekór ojcu, chce być profesjonalnym aktorem, zaistnieć $\mathrm{w}$ dużo bardziej ambitnym repertuarze. Zderzenie dwóch światów reprezentowanych przez bohaterów filmu, odmiennych sposobów myślenia, zupełnie innych realiów, jest bardzo wymowne.

Kolejny film z udziałem R. Koltaiego i w jego reżyserii Niech żyje pierwszy maja portretuje skomplikowane zależności pomiędzy władzą komunistyczną a podporządkowaną jej społecznością $\mathrm{w}$ pierwszej połowie lat pięćdziesiątych $\mathrm{w}$ małej miejscowości, ale za to o dumnie brzmiącej nazwie Acélváros, czyli Stalinogród. Główny bohater, popularny i lubiany wujek Csocsó, jest w zasadzie nowym wcieleniem zarówno Samby seniora, jak i Szwejka z powieści Jaroslava Haška. Od Piszczyka z Zezowatego szczęścia (1960) Andrzeja Munka i Józsefa Pelikána ze Świadka (A tanú, 1969) Pétera Bacsó odróżnia go to, że wpadając w niezliczone kłopoty, potrafi jednak z nich wyjść obronną ręką za sprawą sprytu i wrodzonej inteligencji. Już od samego początku filmu wiadomo, że nie należy do ulubieńców władzy komunistycznej, za kolejne nieposłuszeństwo zesłano go do kamieniołomów, chociaż oficjalnie przebywa na leczeniu w sanatorium. Szybko jednak wychodzi na wolność, bowiem władza go potrzebuje, Csocsó posiada wrodzony talent organizacyjny, tylko on jest w stanie zmobilizować lokalną drużynę piłkarską, by wreszcie odniosła zwycięstwo, potrafi także (właśnie dlatego władza przymyka oczy na jego niesubordynację) przygotować odpowiednią oprawę uroczystości z okazji święta 1 Maja. Nie można jednak pozostawić go bez kontroli, mogłoby to okazać się katastrofalne skutkach, z tego powodu patrzeć mu na ręce będzie pierwszy sekretarz partii w mieście i oficer służby bezpieczeństwa. Pełni obaw, co 
do słuszności wyboru kandydata do tego odpowiedzialnego zadania, zdają sobie sprawę, że nie znajdą nikogo lepszego w całym Acélváros.

Obraz prowincji w czasach komunizmu na Węgrzech Koltai uzupełnia filmem Numer światowy, opowiadając trochę pogmatwane losy bliźniaków, artystów cyrkowych Dodó i Naftalin od początków lat pięćdziesiątych przez rewolucję 1956 roku, aż do dekady lat siedemdziesiątych. To kolejny film Koltaiego, który $\mathrm{z}$ dwoma wspomnianymi wcześniej tworzy pewnego rodzaju tryptyk. Jeden z braci, w oczekiwaniu na dzień uwolnienia drugiego, (za przypadkowe ośmieszenie towarzysza Mátyása Rákosiego trafił do więzienia) jako inspicjent dorabia $\mathrm{w}$ prowincjonalnym teatrze. Kolejne premiery odbywają się z dala od wielkiej polityki i ważnych wydarzeń, aż przychodzi pamiętny październik. Życie na Węgrzechna kilkanaście dni życie obraca się o 180 stopni. Na przykładzie małej społeczności, w której funkcjonuje teatr, widać wyraźnie, jak prowincja w pojęciu nie tylko geograficznym była $\mathrm{z}$ dala od życia Budapesztu. Ludzie nie interesowali się polityką, oni także jej nie rozumieli, dlatego też, kiedy dotrze do nich wiadomość o demonstracjach pod węgierskim parlamentem, nie będzie chętnych, by drążyć ten temat. Dyrektor w tym gorącym okresie zaplanował, jak mu się zdawało, premierę wyjątkowo apolitycznego dzieła, ale wystarczyło jedno zdanie ze sceny, by ktoś z publiczności, bardziej zorientowany politycznie (może ze stolicy) podchwycił je jako przejaw solidarności z manifestantami i okrzykami Ruscy do domu! przerwał przedstawienie. Potem, przez moment, mamy do czynienia z filmem drogi, kiedy Naftalin w ogólnym chaosie postanawia uwolnić brata. Na swej drodze spotyka zagubioną załogę radzieckiego czołgu usilnie poszukującą sposobu, by dostać się nad Kanał Sueski. Jak widać, stosunkowo niewielki obszar kraju wystarcza, by pomylić kierunki. Wspólna podróż przeplatana jest śpiewaniem pieśni przy ognisku, nie tylko zresztą po rosyjsku, bowiem żołnierze charakteryzują się mocno azjatyckimi rysami twarzy. Wreszcie docierają do więzienia, w którym zdezorientowanemu naczelnikowi główny bohater oświadcza, że w towarzystwie rosyjskich czołgów przyjechał po brata, by zabrać go do Budapesztu. Pokazuje nawet jakiś dokument, ale zdecydowanie większe wrażenie robi jednak pancerny pojazd. Cechą charakterystyczną filmów z udziałem Koltaiego jest formuła komediowa. Taki sposób prezentacji relacji społecznych, politycznych w przestrzeni prowincji pozwala odnieść złudne wrażenie, że stalinizm na Węgrzech, a przynajmniej z dala od stolicy kraju, był modelem mniej represyjnym, a bardziej komicznym ${ }^{5}$, w którym inteligentne jednostki kompromitowały mało rozgarniętych przedstawicieli władz, szczególnie pracowników bezpieki. Pozostała część społeczeństwa bezwolnie wykonuje polecenia. Jak słaby jest to reżim, widać po zachowaniu samych oficjeli, którzy np. w obrazie Niech żyje pierwszy maja w zaciszu domowym słuchają

${ }^{5}$ J. Veress, A Magyar Film Története. Budapest, s. 54. 
Radia Wolna Europa, a tylko na użytek innych wygłaszają tezy, że komunista może mieć tylko jednego przyjaciela - partię. Obok humorystycznych wątków przewijają się też poważniejsze tony, chociażby te ukazujące, jak daleko posunięta była indoktrynacja: dzieci godzinami powtarzały mało zrozumiałe dla siebie hasła, ćwiczyły do upadłego choreografię na akademię, natomiast aparat partyjny martwił się np. stanem drogi przed 1 Maja, bo „nią przyjadą towarzysze z Budapesztu”.

Przestrzeń prowincji została dostrzeżona przez twórców tzw. młodego pokolenia. Ferenc Török, znany dobrze polskiej publiczności za sprawą swojego doskonałego debiutu Plac Moskwy (Moszkva Tér, 2001), w kolejnym dziele pt. Sezon (Szezon, 2004), sięga po współczesną historię grupy dwudziestolatków, którzy z małej miejscowości pod Debreczynem wyruszają w podróż, by przeżyć przygodę swojego życia. W przeciwieństwie do wcześniej omawianych filmów z Koltaiem w roli głównej, nie ma $\mathrm{w}$ tym filmie nuty sentymentu do minionego systemu, młodzi ludzie chcą natomiast radykalnie zmienić swoje życie, w którym naprawdę nic się nie dzieje. Jednak kierunek przez nich obrany to nie Budapeszt, ale Balaton $\mathrm{w}$ okresie wakacyjnym, co sprawia, że znajdują sezonową pracę $\mathrm{w}$ jednym $\mathrm{z}$ domów wczasowych. Już w pierwszych kadrach filmu widać, że w ich miasteczku, poza wielką cukrownią, dyskoteką i stacją kolejową, nie ma już w zasadzie niczego. F. Török doskonale pokazał nudę, której niewolnikami są bohaterowie filmu, usilnie próbują zabić czas, znaleźć dla siebie jakiekolwiek zajęcie. W filmie poza nielicznymi momentami wydarzenia rozgrywają się powoli, ślamazarnie, jakby rozleniwione lejącym się z nieba upałem. Poraża brak widoków na zmianę tej smutnej sytuacji, tylko cud mógłby wyrwać ich z obezwładniającego marazmu. Przeprowadzka nad Balaton (sami nie do końca wiedzą, po której stronie „węgierskiego morza" się znaleźli) niewiele w tej materii zmienia. Monotonną pracę próbują urozmaicić sobie np. krótkim udziałem filmie pornograficznym, podpaleniem własnego samochodu, czy awanturą na weselu lokalnych prominentów. Török wiarygodnie portretuje realia prowincji, stereotypy w tym przypadku okazują się prawdziwe, człowiek, by wyrwać się z krępujących go ograniczeń, musi także pokonać bariery w sferze mentalnej. Kwestia wciąż aktualnego podziału kraju, wielkich różnic, skromnych możliwości, perspektyw mieszkańców prowincji wciąż i niezmienne interesuje węgierskich filmowców, słusznie dostrzegają oni w tym zagadnieniu źródło ciekawych, ważnych i autentycznie prawdziwych historii wartych przeniesienia na ekran. Odczuwalna jest w większości tych produkcji pewnego rodzaju nostalgia. Nie dotyczy ona prowincji jako konkretnego miejsca, ale bardziej przestrzeni, gdzie swoją znaczącą rolę odgrywa charakterystyczny sposób życia, relacje społeczne, których pozbawiona jest stolica. Uczucie to jest ponadczasowe, niezależne od epoki, ustroju politycznego, mieszkańcy prowincji funkcjonują według specyficznych reguł w czasach monarchii, w epoce stalinowskiej i kádárowskiej oraz współcześnie. 


\section{BIBLIOGRAFIA}

Gy. Báron, Három trilógia. „Filmkultúra” 1992, nr 2.

Gy. Báron, Repríz. „Filmvilág” 1996, nr 4.

G. Bikácsy, A kukkoltatók. „Filmvilág” 1986, nr 7.

B. Górlaczyk, Wegierski pakiet. Warszawa 2000.

T. Hirsch, Reinkarnációink. „Filmvilág” 2002, nr 1.

J. Kochanowski, Wegry. Od ugody do ugody. Warszawa 1997.

L. Kolozsi, Van másik. „Filmvilág” 2004, nr 12.

G. Kövesdy, Recept nélkül. „Filmvilág” 1997, nr 12.

Nemeskürty, A magyar film története. Budapest 1965.

Romsics, Magyarország Története A XX. Században. Budapest 2005.

G. Schubert, Sose halunk meg. „Filmvilág” 1993, nr 03.

B.Varga, (szer.), Magyar filmográfia. Játékfilmek 1931-1998. Budapest 1999.

J. Veress, A magyar film története. Budapest 2006.

K. Żórawski, Samotna Emma, nieszczęsna Böbe. „Kino” 1992, nr 9.

\section{Filmografia}

Kocham Budapeszt (I love Budapest, 2001), Agnes Incze.

Kochana Emmo, droga Böbe (Édes Emma, drága Böbe - vázlatok, aktok, 1992), István Szabó.

Krewni (Rokonok, 2006), István Szabó.

Niech żyje pierwszy maja (Csócsó, vagyis éljen május elseje, 2001), Róbert Koltai

Nigdy nie umrzemy (Sose halunk meg, 1993), Róbert Koltai.

Numer światowy (Világszám, 2004), Róbert Koltai.

Poduszka Jadwigi (Jadviga párnája, 1999), Krisztina Deák.

Samba (Szamba, 1996), Róbert Koltai

Sezon (Szezon, 2004), Ferenc Török.

Światto na twarzy (Oldás és kötés, 1963), Miklós Jancsó. 